\begin{tabular}{|c|c|c|}
\hline & Int.J.Curr.Microbiol.App.Sci (2016) 5(8): 769-784 & \\
\hline & International Journal of Current Microbiology and Applied Sciences & \\
\hline & ISSN: 2319-7706 Volume 5 Number 8 (2016) pp. 769-784 & \\
\hline EXCELLENT & Journal nomepage. nttp.// www.1jcmas.com & \\
\hline PUBLISHERS & & wwwwijemas.ce \\
\hline
\end{tabular}

Original Research Article

http://dx.doi.org/10.20546/ijcmas.2016.508.086

\title{
Screening of Antifungal Potential of Rhizospheric Isolates against Alternaria Leaf Blight Disease of Bt-cotton in vitro
}

\author{
Laxman S. Raut ${ }^{1 *}$ and Venkat S. Hamde ${ }^{2}$ \\ ${ }^{1}$ Department of Microbiology, Sant Tukaram Arts and Science College, \\ Parbhani-431401, Maharashtra, India \\ ${ }^{2}$ Department of Microbiology, Yogeshwari Mahavidyalaya, Ambajogai -431517, \\ Maharashtra, India \\ *Corresponding author
}

\begin{abstract}
A B S T R A C T
Keywords

Bt-cotton, Alternaria leaf blight, Alternaria macrospora, volatile metabolites, diffusible metabolites and siderophore.

\section{Article Info}

Accepted:

28 June 2016

Available Online:

10 August 2016

Alternaria leaf blight is one of the most important yield reducing diseases of Btcotton caused by Alternaria macrospora. In order to find bio-based ecofriendly effective control measure to this phytopathogen, 114 rhizospheric bacterial isolates were screened for in vitro antifungal potential against Alternaria leaf blight phytopathogen using modified dual culture method. Out of 114 isolates tested, 18 rhizospheric bacterial isolates inhibited growth of Alternaria macrospora in vitro. Highest antifungal activity was exhibited by isolate RLS19 (91.43\%) and followed by RLS52 (88.57 \%), RLS18 (85.71\%), RLS102 (85.71\%), RLS76 (82.86 \%), RLS96 $(82.86 \%)$ in dual culture technique against the phytopathogen. Based on inhibition activities in dual culture assay, 8 efficient rhizospheric bacterial isolates were selected for further investigation. For characterizations of microbial control mechanism, rhizospheric bacterial isolates were tested for production of volatile metabolites, diffusible metabolites and siderophore. Volatile metabolite production was detected by double plate assay. Rhizospheric bacterial isolate RLS76 hamper $17.77 \%$ radial growth by producing volatile metabolites against phytopathogen while other isolates were unable to produce volatile metabolites. Diffusible metabolite production was detected by agar well diffusion method. Rhizospheric bacterial isolates RLS19 and RLS76 showed highest (71.43\%) inhibition of phytopathogen by producing diffusible metabolites followed by RLS18 (68.57.00 $\%)$, RLS52, RLS56, RLS96, RLS102 (65.71 \%) and RLS53 (57.14 \%). Siderophore production ability was detected qualitatively by modified CAS agar plate method. All the tested, 8 rhizospheric bacterial isolates were able to produce siderophore. The highest siderophore was recorded by RLS18, RLS53 and RLS58.
\end{abstract}

\section{Introduction}

Alternaria leaf blight disease caused by Alternaria macrospora (Zimm.) and Alternaria alternata (Fr.) Keissler is one of the most predominant diseases of Bt-cotton having national and regional significance. This disease is worldwide in distribution and reported from all cotton growing countries 
of world (Hillocks, 1991). Alternaria leaf blight disease of cotton is common and reported variable percent disease incidence (PDI) from South zones (10-35 \%), North zone (7.33 to $31.83 \%$ ) and Central zone (9.66 to $31.30 \%$ ) of India. This disease was reported for the first time from Dharwad district of Karnataka and also in Pune and Ahmednagar district of Maharashtra, India (Rane and Patel, 1956).

Alternaria leaf blight disease is seed borne (Bashan and Levanony, 1987; Arabsalmani, 2015) and long range dispersal within planting seed. Alternaria macrospora and Alternaria alternata are dispersed by wind within a crop and to a certain extent from field to field (Bashan et al., 1991a). Alternaria leaf blight of cotton is essentially a disease complex caused by two pathogens, Alternaria macrospora and Alternaria alternata (Bashan et al., 1991b). Alternaria macrospora is the most prevalent pathogen during the early growing season and Alternaria alternata towards the end of the growing season (Bhuiyan et al., 2007). Alternaria macrospora can cause leaf spot, stem cankers, defoliation and boll shedding of cotton. Biochemical studies reveled that both non- $\mathrm{Bt}$ and $\mathrm{Bt}$ genotypes of cotton were found equally susceptible to the Alternaria leaf blight disease (Govindappa et al., 2008).

Traditionally, Alternaria leaf blight disease was controlled by the application of synthetic fungicides. Propiconazole and Taqat were most widely used chemical fungicides for controlling most of the foliar disease of cotton (Kapadiya et al, 2015). Indiscriminate use of chemical fungicides with various group of active compound resulted in the accumulation of residual toxicity, environmental pollution, altered the ecological balance in the soil by over killing the non-targeted microorganisms and developed resistance to the pathogen.
Microbiological control of plant pathogen by rhizospheric microorganisms offers an attractive alternative over chemical control. There are some evidences that microorganism can be served as good microbial control candidate to suppress the diseases. Researchers from different region reported microorganisms as biocontrol agents such as Pseudomonas sp (Chernin et al., 2011; Sandheep et al., 2012), Bacillus sp (Saha et al., 2012; Lamsal et al., 2012), Trichoderma sp (Ajith and Lakshmidevi, 2010; Otadoh et al., 2011; Sandheep et al., 2012) and Serratia sp (Chernin et al., 2011). Several researchers are working on biological control of Alternaria sp. of different crops but there is less literature available on microbiological control of Alternaria leaf blight of Bt- cotton. Biological Control of Alternaria blight of cotton was studied by using Trichoderma sp. (Dalpati et al., 2010; Dighule et al., 2011; Gveroska and Ziberoski, 2012; Gholve et al., 2014; Thakur and Harsh, 2014), Pseudomonas sp. ((Rajput et al., 2013; Gholve et al., 2014; Thakur and Harsh, 2014; Kapadiya et al, 2015) and Bacillus sp. (Abbo et al., 2014; Abdalla et al., 2014). Still Alternaria leaf blight causes economic losses to farmers. So it is necessary to search efficient new microbiological control agents to control the disease.

Soil serves as excellent culture medium for all types of microorganisms due to the abundant availability of nutrient and favorable environmental condition. Rhizosphere of plants has been frequently exploited as brilliant source for searching microbial control agents. It has been suggested that microorganisms isolated from the rhizosphere of a particular crop may be better adapted to that crops rhizospheric environment and may provide better control of diseases than the other plant rhizosphere species (Hebbar et al., 1991). 
Considering the seriousness of the Alternaria leaf blight disease and to avoid yield losses and hazardous effect of agrochemical the present study was aimed to i) Isolation and pathogenicity testing of phytopathogen responsible for causing Alternaria leaf blight of Bt-cotton, ii) isolation of rhizospheric bacterial isolates from healthy Bt-cotton plant iii) in vitro screening of rhizospheric bacterial isolates for antifungal activity against Alternaria leaf blight pathogen and iv) characterization of in vitro microbial control mechanism of efficient rhizospheric isolates.

\section{Materials and Methods}

\section{Isolation of Phytopathogen causing Alternaria leaf blight}

Infected leaves of Bt-cotton plants showing the characteristic symptoms of Alternaria leaf blight disease were collected in sterile polyethylene bags from different districts of Marathwada region and brought to research laboratory. Leaves were washed with tap water to remove phylloplane organisms. Each diseased leaf was cut into small pieces $(5-10 \mathrm{~mm})$, washed with sterile distilled water and surface sterilized with $0.1 \%$ mercuric chloride for two minutes. Surface sterilized tissues were rinsed with three changes of sterile distilled water to remove the traces of $\mathrm{HgCl}_{2}$. Four pieces were transferred on PDA medium with sterile forceps (Pryor and Michailides, 2002) in 90 $\mathrm{mm}$ Petri-dishes and then incubated at room temperature for 6-7 days.

\section{Pathogenicity Test}

Pathogenicity test was conducted on detached Bt cotton leaves by wounded leaf assay method in moist chamber (Pryor and Michailides, 2002). The young Bt cotton leaves were placed in moist chamber plates on glass slides. For wounded leaf assays, each leaf was slightly wounded on the midrib with a sterile surgical blade prior to inoculation. To inoculate leaves, a conidial suspension was placed on each leaf wound. While leaves placed in moist chamber plates without inoculation of conidial suspension serve as control. The plates were incubated at room temperature for 7 days and watered regularly. After incubation, resulting lesions were observed. This experiment was conducted in triplicates.

\section{Isolation of rhizospheric bacteria}

Rhizospheric soil samples from healthy Btcotton growing fields of different districts of Marathwada region (Beed, Latur, Osmanabad, Jalna, Aurangabad, Nanded, Hingoli and Parbhani) were collected in sterile polyethylene bags and brought to research laboratory, $1 \mathrm{~g}$ of each rhizospheric soil sample was mixed with $100 \mathrm{ml}$ sterile distilled water and shaken well for $2 \mathrm{~min}$, and then the content of flask was allowed to settle. Different dilutions, $10^{-1}$, to $10^{-6}$ of these samples were prepared by serial dilution technique and highest dilutions i.e. $10^{-4}, 10^{-5}$ and $10^{-6}$ were used for plating propose. $0.5 \mathrm{ml}$ selected dilutions were transferred aseptically in sterile Petri plate and plates were poured with molten melted nutrient agar. The plates were rotated clockwise and anti-clockwise direction to mix the content of the plate. Allowed it to solidify and all the inoculated plates were incubated at room temperature for 24-48 h.

\section{In vitro Screening for microbial control agent}

As number of rhizospheric bacterial isolates was too high, for screening of such huge number of antagonist there was need of multiple cultures testing method. For that purpose we slightly modified the technique 
suggested by Dennis and Webster (Dennis and Webster, 1971). To standardize our technique, a template was made from cardboard in the shape of an equilateral triangle with the sides $52 \mathrm{~mm}$ in length and $30 \mathrm{~mm}$ from the center. Individual bacterial colony was inoculated along the vertices of the triangle (BC). Fungal disc was placed at the center (FC) so that the plug was at a maximum distance of $30 \mathrm{~mm}$ from the bacterial streak (Fig.1).

114 rhizobacteria isolates were screened for antifungal activity against Alternaria macrospora by using modified dual culture technique on King B agar plates (Gull and Hafeez, 2012). $5 \mathrm{~mm}$ diameter mycelial disc was punched from margin of actively growing mycelium of Alternaria macrospora and placed at the center of 90 $\mathrm{mm}$ Petri plate and rhizobacterial isolates were inoculated $30 \mathrm{~mm}$ apart from the center. Three rhizospheric bacterial isolates were placed in a plate along with phytopathogen at the center. Control plate was kept without inoculation of rhizobacteria isolates and all the plates were incubated at room temperature for 6 days. The antifungal activity was determined by measuring the inhibition of mycelial growth of Alternaria macrospora.

Efficient rhizospheric bacterial isolates in modified dual culture technique were again evaluated by using dual culture technique (Dennis and Webster, 1971). In which $5 \mathrm{~mm}$ diameter mycelial disc was punched from margin of actively growing mycelium of Alternaria macrospora with sterile cork borer. Both pathogen and antagonist rhizobacterial isolates was inoculated 10 $\mathrm{mm}$ away from the center in $90 \mathrm{~mm}$ Petri plate containing Kings B agar. The resultant distance was $20 \mathrm{~mm}$ in between pathogen and antagonist in $90 \mathrm{~mm}$ Petri plate. Control plate was kept without inoculation of rhizobacteria isolates and all the plates were incubated at room temperature for 6 days. The antifungal activity was determined by measuring the inhibition of mycelial growth of Alternaria macrospora using the formula (Whipps, 1987).

$\mathrm{PI}=\frac{\mathrm{R} 1-\mathrm{R} 2}{\mathrm{R} 1} \times 100$

Where, $\mathrm{R} 1$ is radial growth by the pathogen in the opposite direction of the antagonist (a control value) and R2 is radial growth by the pathogen in the direction towards the antagonist (an inhibition value).

\section{Mechanism of Biocontrol agents}

To characterize the mechanism of microbial control agents, the efficient rhizospheric bacterial isolates were tested for the production of volatile metabolites, diffusible metabolites and production of siderophore.

\section{Detection of volatile metabolites}

Volatile metabolites detection of efficient rhizospheric bacterial isolates was done by using double plate method (Dennis and Webster, 1971). The kings-B agar plate inoculated with a $5 \mathrm{~mm}$ mycelial disc of Alternaria macrospora and rhizospheric isolate at the center of $90 \mathrm{~mm}$ Petri plate separately. Both the inoculated plates were placed facing each other and sealed with cellophane adhesive tape. Control was kept without inoculation of rhizospheric isolate. Procedure repeated for each efficient rhizospheric bacterial isolates in triplicates. All the plates were incubated at room temperature for 6 days. The production of volatile metabolites was then determined by measuring inhibition of Alternaria macrospora and percentage of radial growth inhibition was calculated by using the formula (Whipps, 1987). 


\section{Detection of diffusible metabolites}

Diffusible antifungal metabolites were detected by well diffusion assay (Sadfi et al., 2002). Rhizobacterial isolates showing antifungal activity against Alternaria macrospora during screening were grown in King B broth at room temperature on rotary shaker at $150 \mathrm{rpm}$ for $36-48 \mathrm{~h}$ to obtain cell free culture filtrate. Kings B agar plates were prepared and after solidification with the help of sterile cork borer three wells 30 $\mathrm{mm}$ apart from the center $90 \mathrm{~mm}$ diameter were punched on a agar plate. These wells were labeled according to the rhizobacteria isolates cell free culture filtrate to be loaded. $5 \mathrm{~mm}$ plugs from leading edge of 3 day old culture of Alternaria macrospora were punched and kept at the center of the plate. Different rhizobacterial isolate broths were filtered by using Millipore syringe filter 0.22 $\mu$ (Hi-media) to prepare filtrate for diffusible metabolites. Each well was loaded with 100 $\mu 1$ cell free culture filtrate aseptically. Control was kept without inoculation of rhizobacterial cell free culture filtrate. All the plates were incubated at room temperature for 6 days. Plates were observed for zone of inhibition. Percentage of radial growth inhibition was calculated by using the formula (Whipps, 1987).

\section{Qualitative Detection of siderophore}

Siderophore production was determined by using modified Chrome Azurol S (CAS) assay (Milagres et al., 1999). Initially all the glassware's are rinsed with distilled water and dried. $60.5 \mathrm{mg}$ of CAS was weighed accurately and dissolved in $50 \mathrm{ml}$ of distilled water and to this add $10 \mathrm{ml}$ of iron solution (1 $\mathrm{mM} \mathrm{FeCl} 3 \cdot 6 \mathrm{H}_{2} \mathrm{O}$, in $10 \mathrm{mM} \mathrm{HCl}$ ). 72.9 mg of Hexa decyl tri methyl-ammonium bromide (HDTMA) dissolved in $40 \mathrm{ml}$ distilled water. CAS and Iron solution mixture was slowly added to $40 \mathrm{ml}$ HDTMA with constant stirring to obtain dark blue colour. Basal Medium containing $30.24 \mathrm{~g}$ Pipes, and $12 \mathrm{~g}$ of a $50 \%$ (w/w) $\mathrm{NaOH}$ to rise the $\mathrm{pH}$ to the $\mathrm{pKa}$ of Pipes (6.8) and 15 g Agar in $750 \mathrm{ml}$ distilled water. All the contents are separately sterilized by autoclaving at $121^{\circ} \mathrm{C}$ for $15 \mathrm{~min}$. After cooling to $50{ }^{\circ} \mathrm{C}$ in $750 \mathrm{ml}$ basal medium add $100 \mathrm{ml}$ CAS-Fe-HDTMA mixture along the glass wall and agitated with enough care to avoid foaming. Petri dishes $(90 \mathrm{~mm}$ in diameter) were prepared with $30 \mathrm{ml}$ of Nutrient agar medium for culturing rhizospheric isolates. After solidification, the medium was cut into halves, one of which was replaced by CAS blue agar (15 $\mathrm{ml}$ ) and allowed to solidify. The halves containing Nutrient agar medium was inoculated with $24 \mathrm{~h}$ old rhizospheric isolate near the borderline of the two medium. The same procedure was repeated for each rhizospheric isolate. Un-inoculated CAS agar plate serves as control. All plates were incubated at room temperature for 5 days and change in CAS agar colour from blue to orange or purple or dark purplish- red indicates the siderophore production.

\section{Results and Discussion}

\section{Isolation of phytopathogen and pathogenicity testing}

Alternaria leaf blight phytopathogen was isolated from infected leaf of Bt-cotton plant. The phytopathogen produced black to olive brown colonies and was suede-like to floccose growth on inoculated PDA plates (Fig 2a). The mycelium was septate, hyaline and branched. Conidia were solitary, dark brown, slightly flexous, muriform and ellipsoidal with tapering long beak. The size of conidia ranged from 25-57.5 x 12.5-25 $\mu \mathrm{m}$ with 1 to 6 transverse septa and 0 to 2 longitudinal septa. Size of the beak ranged from 5-15 x 5-7.5 $\mu \mathrm{m}$ [Fig 2(b) and 2(c)]. 
Based upon these characters the phytopathogen was identified as Alternaria macrospora (Ellis, 1976). The isolated fungal mycelium growth was transferred on fresh PDA and purified. The phytopathogen was further transferred to fresh PDA and Kings B agar plates and also maintained on slants for further use.

Pathogenicity test was carried out to prove the Koch postulates by detached leaf inoculation method in moist chamber (Pryor and Michailides, 2002). After 7 days of incubation previously isolated pathogen was able to infect the leaf and develop the symptoms of Alternaria leaf blight of $\mathrm{Bt}$ cotton (Fig.3). The pathogen was again reisolated from artificially infected leaf by using PDA medium. The characters of reisolated pathogen and previously isolated pathogen used for inoculation were same. Hence, Koch postulates were proved.

\section{Isolation of rhizospheric bacteria}

114 rhizobacterial isolates were isolated from rhizospheric soil samples from different Bt-cotton fields by using serial dilution method. Isolates were selected on the basis of distinctive morphology, size, shape and colour of the bacterial colony and location of the soil sample. All the isolates were tentatively labeled as RLS01 to RLS114 and maintained on nutrient agar slants with periodic transfer to fresh medium for future application,

\section{In vitro Screening for microbial control agent}

All the114 rhizospheric bacterial isolates were screened for in vitro antifungal activity against Alternaria macrospora by modified dual culture technique. Out of 114,18 rhizobacterial isolates inhibited mycelial growth in modified dual culture technique
(Fig. 4). 18 rhizobacterial isolates showing mycelial growth inhibition in modified dual culture technique were again evaluated by dual culture technique (Dennis and Webster, 1971). These isolates showed significant differences in mycelial growth inhibition. Radial growth of phytopathogen in test and control was measured and recorded (Table 1 and Fig. 5). Per cent inhibition Alternaria macrospora was calculated by using the formula (Whipps, 1987). The highest antifungal activity was exhibited by rhizospheric isolate RLS19 (91.43\%) and followed by RLS52 (88.57\%), RLS18 and RLS 102 (85.71\%) and RLS53, RLS76 and RLS96 (82.86 \%.). Based on screening results in dual culture technique, eight isolates (RLS18, RLS19, RLS52, RLS53, RLS56, RLS76, RLS96 and RLS102) with good inhibition activities of Alternaria alternata were selected for further study.

\section{Mechanism of microbial control agent}

\section{Detection of volatile metabolites}

After 6 days incubation it was observed that out of 8 rhizospheric isolate, only one rhizospheric bacterial isolates was able to produce volatile metabolites and inhibits the radial growth of Alternaria macrospora (Fig. 6). Inhibition of phytopathogen by producing volatile metabolites was shown by rhizospheric bacterial isolate RLS76 $(17.77 \%)$. Other seven isolates were unable to produce volatile metabolites and there was no inhibition of Alternaria macrospora growth.

\section{Detection of diffusible metabolites}

Diffusible antifungal metabolites production was studied by well diffusion assay. Eight efficient rhizospheric bacterial isolates tested showed inhibitory effect on Alternaria macrospora by producing 
diffusible metabolites (Fig. 7 and Table 2). Rhizospheric bacterial isolate RLS19 and RLS76 showed highest inhibition of phytopathogen $(71.43 \%)$ by producing diffusible metabolites followed by RLS18 (68.57.00 \%), RLS52, RLS56, RLS96, RLS102 (65.71\%) and RLS53 (57.14\%).

\section{Qualitative detection of siderophore}

After 5 day incubation, eight isolates were produced siderophore on modified CAS agar plate. Siderophore production was recorded in the form of grades (Table 3). The highest siderophore production was recorded in the form of change in colour of the medium from blue to purple or orange (Fig. 8). Highest siderophore producing rhizospheric bacterial isolates were RLS18, RLS53 and RLS58.

Rhizospheric soil serves as excellent culture medium for all types of microorganisms due to the abundant availability of nutrients and favorable environmental conditions. Rhizospheric microorganisms colonize root to survive and proliferate along with growing plant as a native micro flora and serves as front line defense in plants. Plants rhizosphere has been frequently exploited as brilliant source for searching microbial control agents. It has been suggested that microorganisms isolated from the rhizosphere of a particular crop may be better adapted to that crops rhizospheric environment and may provide better control of diseases than the other plant rhizosphere species (Hebbar et al., 1991). Maintaining pathogenic microorganisms affecting plant health and stability of ecosystem it was advised to make greater use of microorganisms as one-time, occasional, or repeated introductions for biological control of plant pathogens (Cook, 1993).

By using infected Bt-cotton leaf, after 6 days incubation we have isolated olive brown with a light border mycelial growth on PDA plates (Fig.2). Based on macro and microscopic observations of mycelial growth, phytopathogen was identified as Alternaria macrospora (Ellis, 1976). It was again confirmed by artificial inoculation of isolated phytopathogen on detached leaf inoculation technique in moist chamber (Pryor and Michailides, 2002). Inoculated pathogen develops the symptoms of Alternaria leaf blight (Fig.3) and it was reisolated in pure culture on PDA. The characteristics of re-isolated and previously isolated pathogens were same Criteria that were established by Robert Koch to identify the causative agent of particular disease was proved by the pathogen.

114 rhizospheric bacterial isolates were isolated with variation in morphological characteristics by using serial dilution technique and pour plate technique. These isolates are tentatively named as RLS01 to RLS114 and preserved for future use. Antifungal potential of rhizospheric bacterial isolate were evaluated by different researchers using dual culture technique (Dennis and Webster, 1971). Fungi belonging to genera Trichoderma, Aspergillus and some bacterial genera Bacillus and Pseudomonas were widely used as biocontrol agent in plant pathology.

Trichoderma have long been recognized as agents for the control of plant disease. The antagonistic fungi Trichoderma viride suppress the radial growth of Alternaria macrospora and highest inhibition percentage was recorded $75.00 \%$ (Gangurde et al., 2003), and followed by $74.77 \%$ (Rajput et al., 2013), 67.41\% (Dighule et al., 2011) and $64.44 \%$ (Dalpati et al., 2010). T. harzianum was evaluated for antifungal potential against Alternaria macrospora the highest inhibition was recorded $90.00 \%$ (Thakur and Harsh, 2014) and followed by $71.25 \%$ (Rajput et al., 2013) and $67.50 \%$ 
(Gangurde et al., 2003). Fungal antagonist Aspergillus inhibited Alternaria macrospora $75.37 \%$ (Dighule et al., 2011) and $67.40 \%$ (Thakur and Harsh, 2014). The bacterial antagonist Bacillus subtilis inhibited 73.66 $\%$ (Dalpati et al., 2010) and 69.73 \% (Rajput et al., 2013) while Pseudomonas fluorescens inhibits $68.88 \%$ (Dalpati et al., 2010) and $56.70 \%$ (Rajput et al., 2013) radial growth of Alternaria sp.

Screening of large number of rhizospheric isolate for antagonism against phytopathogen is very tedious job. There is investment huge amount of medium and time for screening such large cultures. To resolve this problem we slightly modified the method of Dennis and Webster (Dennis and Webster, 1971) by which we test three cultures at a time in single plate. Each culture is having $30 \mathrm{~mm}$ distance away from the pathogen and comparative study of three isolate is possible by this method (Fig.4).

In this method radial inhibition (radius) is considered for calculation of per cent inhibition instead of diameter. This method has advantageous in saving medium and time to evaluate large number of isolates. 114 rhizospheric bacterial isolates were screened for in vitro antifungal activity against Alternaria macrospora by modified dual culture method. 18 rhizospheric bacterial isolates inhibited Alternaria macrospora mycelial growth were again reevaluated by dual culture technique (Dennis and Webster, 1971).

The rhizospheric bacterial isolates showed inhibitory effect towards the fungal growth which was measured in percent inhibition (Whipps, 1987). The highest antifungal activity was shown by rhizospheric isolate RLS19 (91.43 \%) and followed by RLS52 (88.52\%), RLS18 and RLS 102 (85.71\%) and RLS53, RLS76, RLS96 (82.86 \%.).
When results of previous researchers compared to our findings, our finding found more superior than the others, where rhizospheric bacterial isolates RLS19 (91.43 $\%), \operatorname{RLS} 52$ (88.52\%), RLS18 and RLS102 $(85.71 \%)$ were good inhibitors of Alternaria macrospora.

Antifungal potential shown by these different isolates was due to production of volatile metabolite, diffusible metabolite, siderophore hydrolytic enzymes etc. Volatile metabolites produced by Trichoderma $s p$. against Alternaria brassicicola was tested by using double plate method. T. harzianum efficiently reduced the mycelial growth of Alternaria alternata by producing volatile secondary metabolites (Dighule et al., 2011). Volatile metabolites produced by $T$. viride (Tv-1) was found most effective in reducing the mycelial growth of Alternaria brassicicola by $40.75 \%$ followed by $T$. harzianum (Th-2) and $T$. viride (TV-2) recording 34.73 and $34.25 \%$ inhibition respectively over control (Amin et al., 2010). Effect of volatile metabolites produced by $T$. harzianum (T2) on the growth of Alternaria sp. was studied after seven days of incubation.

The maximum mycelial growth inhibition was $39.30 \%$ against Alternaria sp. (ALSaeedi and AL-Ani, 2014). Volatile metabolites detection of 8 rhizospheric bacterial isolates was done by using double plate method (Dennis and Webster, 1971).

Rhizospheric isolate RLS76 only produce volatile metabolites and which was $17.77 \%$ (Fig.6) while other isolates were unable to produce volatile metabolites. Volatile metabolite produced by our isolate was very low as compared other researchers and showed cumulative effect in controlling the phytopathogen. 
Table.1

Table.1 In vitro screening of antibacterial activity rhizospheric bacterial isolates against Alternaria macrospora

\begin{tabular}{|c|c|c|c|c|}
\hline $\begin{array}{c}\text { Sr. } \\
\text { No. }\end{array}$ & $\begin{array}{c}\text { Rhizospheric } \\
\text { isolate }\end{array}$ & $\begin{array}{c}\text { Growth } \\
\text { towards } \\
\text { antagonist in } \\
\text { mm (R2 }\end{array}$ & $\begin{array}{c}\text { Growth of } \\
\text { control in } \\
\text { mm (R1) }\end{array}$ & $\begin{array}{c}\text { \% of } \\
\text { inhibition }\end{array}$ \\
\hline $\mathbf{1}$ & RLS18 & $\mathbf{5}$ & $\mathbf{3 5}$ & $\mathbf{8 5 . 7 1}$ \\
\hline $\mathbf{2}$ & RLS19 & $\mathbf{3}$ & $\mathbf{3 5}$ & $\mathbf{9 1 . 4 3}$ \\
\hline 3 & RLS50 & 10 & 35 & 71.43 \\
\hline $\mathbf{4}$ & RLS52 & $\mathbf{4}$ & $\mathbf{3 5}$ & $\mathbf{8 8 . 5 7}$ \\
\hline $\mathbf{5}$ & RLS53 & $\mathbf{6}$ & $\mathbf{3 5}$ & $\mathbf{8 2 . 8 6}$ \\
\hline 6 & RLS56 & 7 & 35 & 80.00 \\
\hline 7 & RLS60 & 8 & 35 & 77.14 \\
\hline 8 & RLS69 & 15 & 35 & 57.14 \\
\hline 9 & RLS72 & 10 & 35 & 71.43 \\
\hline $\mathbf{1 0}$ & RLS76 & $\mathbf{6}$ & $\mathbf{3 5}$ & $\mathbf{8 2 . 8 6}$ \\
\hline 11 & RLS78 & 9 & 35 & 74.29 \\
\hline 12 & RLS85 & 10 & 35 & 71.43 \\
\hline 13 & RLS95 & 10 & 35 & 71.43 \\
\hline $\mathbf{1 4}$ & RLS96 & $\mathbf{6}$ & $\mathbf{3 5}$ & $\mathbf{8 2 . 8 6}$ \\
\hline 15 & RLS98 & 14 & 35 & 60.00 \\
\hline $\mathbf{1 6}$ & RLS102 & $\mathbf{5}$ & $\mathbf{3 5}$ & $\mathbf{8 5 . 7 1}$ \\
\hline 17 & RLS107 & 8 & 35 & 77.14 \\
\hline 18 & RLS114 & 10 & 35 & 71.43 \\
\hline
\end{tabular}

Table.2

Table.2 In vitro screening of antibacterial activity rhizospheric bacterial isolates against Alternaria macrospora

\begin{tabular}{|c|c|c|c|c|}
\hline $\begin{array}{c}\text { Sr. } \\
\text { No. }\end{array}$ & $\begin{array}{c}\text { Rhizospheric } \\
\text { isolate }\end{array}$ & $\begin{array}{c}\text { Growth } \\
\text { towards } \\
\text { antagonist } \\
\text { in mm }(\mathbf{R 2}\end{array}$ & $\begin{array}{c}\text { Growth of } \\
\text { control in } \\
\text { mm (R1) }\end{array}$ & $\begin{array}{c}\text { \% of } \\
\text { inhibition }\end{array}$ \\
\hline 1 & RLS18 & 11 & 35 & 68.57 \\
\hline $\mathbf{2}$ & RLS19 & $\mathbf{1 0}$ & $\mathbf{3 5}$ & $\mathbf{7 1 . 4 3}$ \\
\hline 3 & RLS52 & 12 & 35 & 65.71 \\
\hline 4 & RLS53 & 15 & 35 & 57.14 \\
\hline 5 & RLS56 & 12 & 35 & 65.71 \\
\hline $\mathbf{6}$ & RLS76 & $\mathbf{1 0}$ & $\mathbf{3 5}$ & $\mathbf{7 1 . 4 3}$ \\
\hline 7 & RLS96 & 12 & 35 & 65.71 \\
\hline 8 & RLS102 & 12 & 35 & 65.71 \\
\hline 9 & Control & 0 & 70 & 100.00 \\
\hline
\end{tabular}


Table.3

\begin{tabular}{|c|c|c|}
\hline Sr. No. & $\begin{array}{l}\text { Rhizospheric } \\
\text { isolate }\end{array}$ & Siderophore production \\
\hline 1 & RLS18 & +++ \\
\hline 2 & RLS19 & ++ \\
\hline 3 & RLS53 & +++ \\
\hline 4 & RLS52 & ++ \\
\hline 5 & RLS58 & +++ \\
\hline 6 & RLS72 & ++ \\
\hline 7 & RLS79 & ++ \\
\hline 8 & RLS102 & ++ \\
\hline 9 & Control & - \\
\hline
\end{tabular}

Fig.1 Cardboard template for standardization dual culture technique for antifungal activity
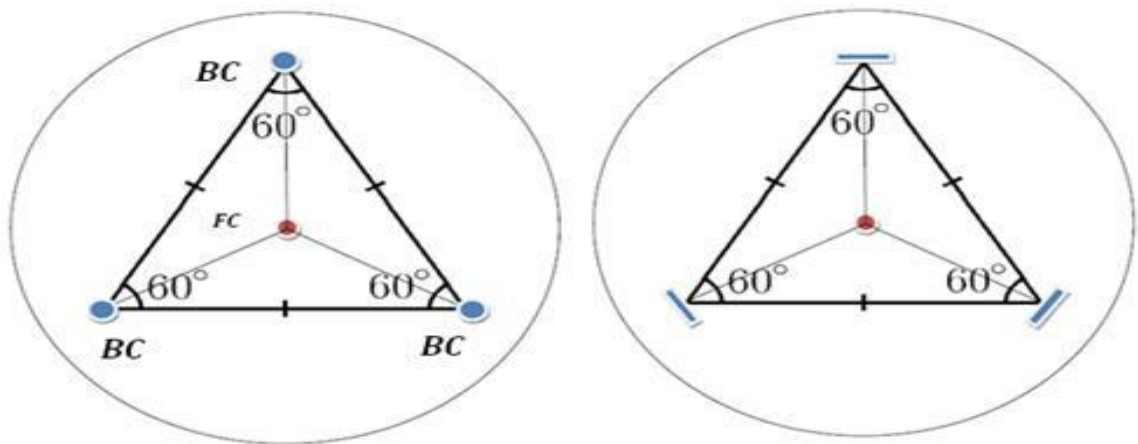

Fig.2 Isolation of Alternaria leaf blight causing phytopathogen from infected Bt-cotton leaf (a) isolated Alternaria leaf blight pathogen from infected cotton leaf, (b) microscopic mycelium with spores at 45X and (c) spore morphology Phytopathogen at 100X.

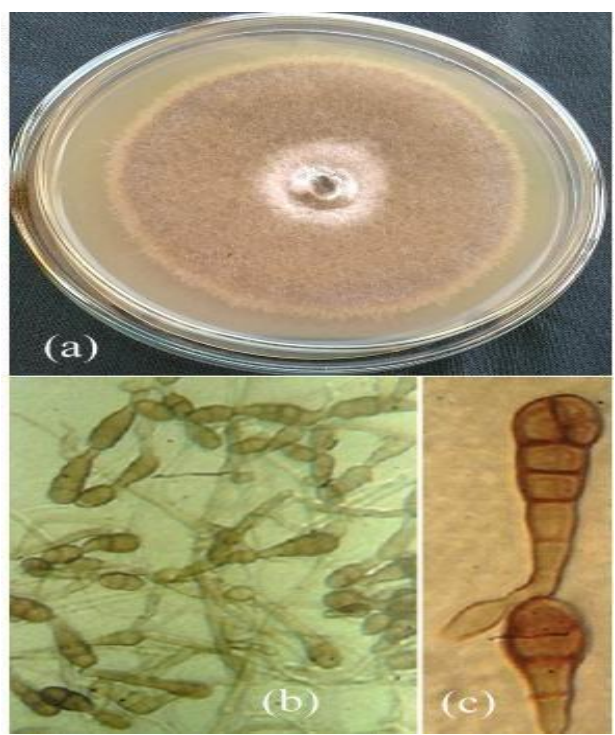


Fig.3 Pathogenicity testing of isolated pathogen of Alternaria leaf blight of Bt cotton on detached leaf by moist chamber method (a) control un-inoculated leaf, (b) and (c) leaf inoculated with isolated phytopathogen showing symptoms of Alternaria leaf blight and (d) Microscopic spore from artificially infected leaf of cotton.

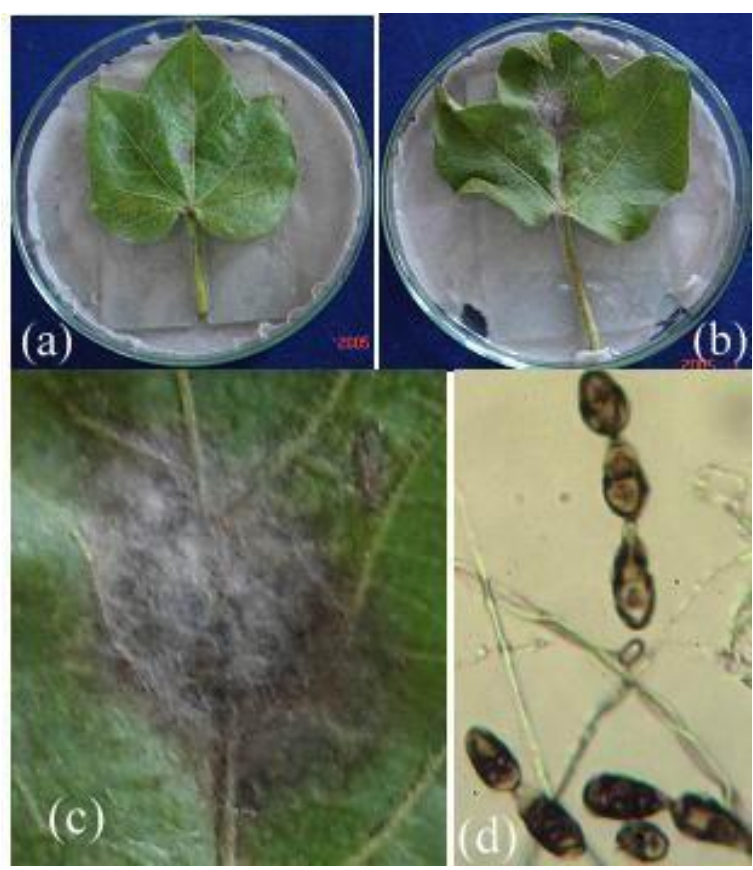

Fig.4 In vitro screening of antifungal activity of rhizospheric isolates against Alternaria macrospora by tri-culture method (a) Control and (b) Pathogen + Rhizospheric isolates
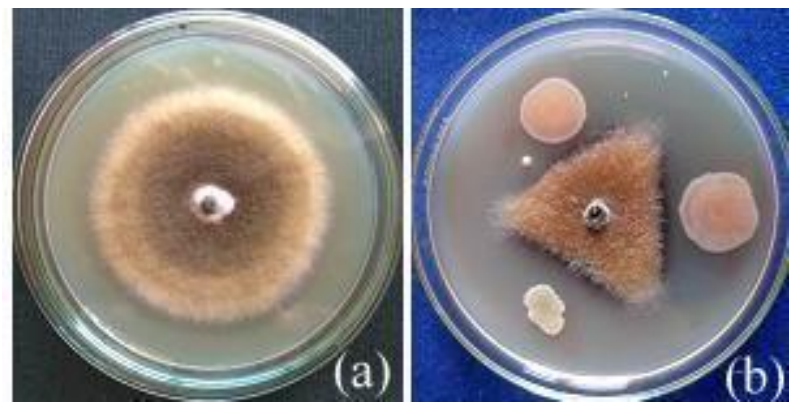
Fig.5 In vitro antifungal activity of rhizospheric isolates against Alternaria macrospora (a) Control (b) RLS19 (c) RLS52

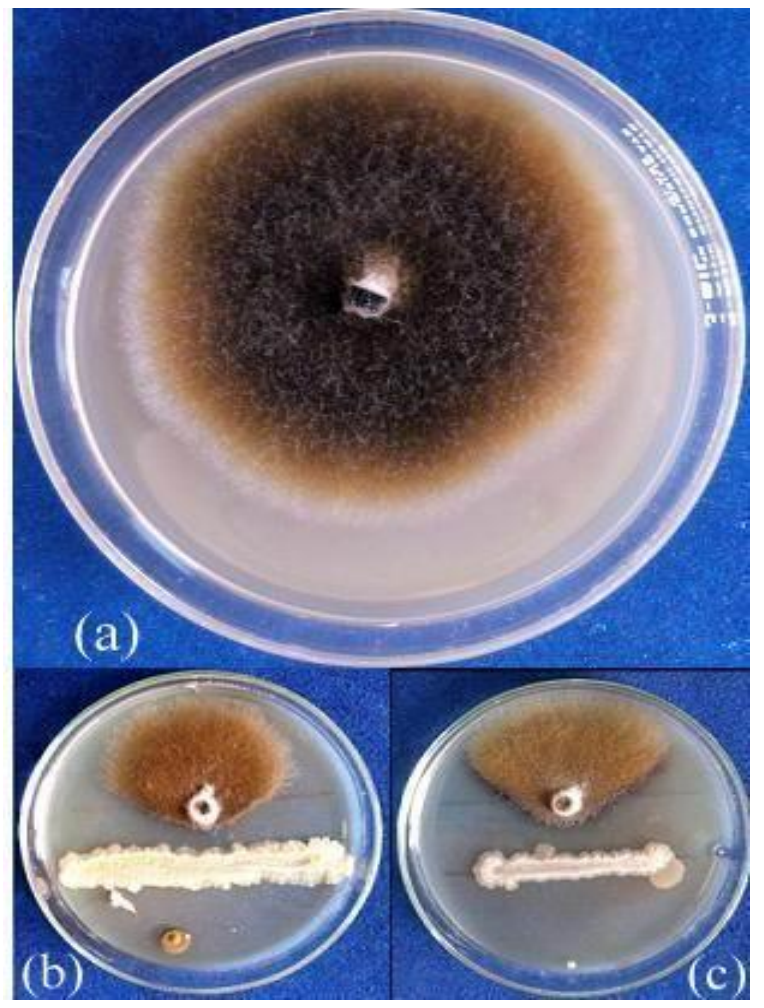

Fig.6 Detection of volatile antifungal metabolite production of rhizospheric isolate RLS76 against Alternaria macrospora (a) Control and (b) Test

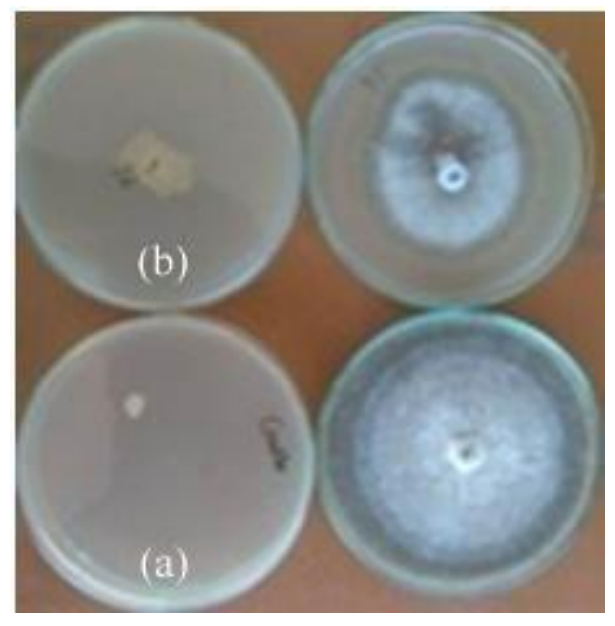


Fig.7 Detection of diffusible antifungal metabolites production of rhizospheric isolate by agar well diffusion method against Alternaria macrospora (a) Control, (b) RLS56, (c) RLS76, and (d) RLS96
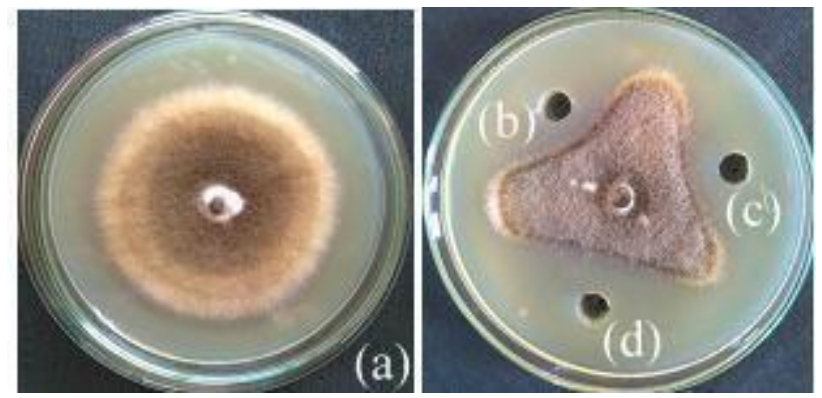

Fig.8 Siderophore production of rhizospheric isolates by modified CAS assay (a) Control, (b) RLS18, (c) RLS58 and (d) RLS53

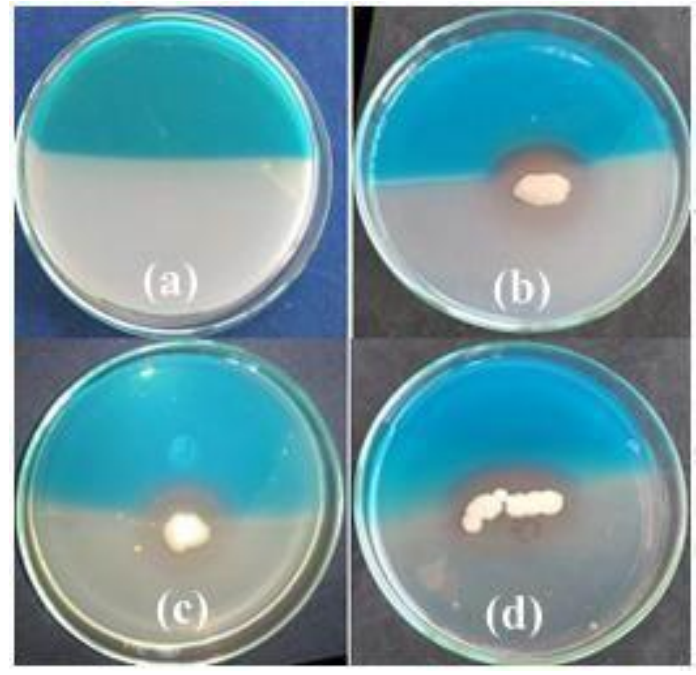

Diffusible antifungal metabolites production was tested by well diffusion assay (Sadfi et al., 2002). Trichoderma sp. produced diffusible and volatile metabolites (Ghildyal and Pandey, 2008). In Alternaria sp. there was remarkable increase in growth inhibition at the treatment with $T$. harzianum cell free culture filtrates that collected after 6 and 9 days of incubation which were $58.75 \%$ and $56.43 \%$ respectively whereas, less inhibition effect (48.57\%) was recorded at the treatment with filtrates that collected after 12 days of incubation (AL-Saeedi and AL-Ani, 2014). Eight efficient rhizospheric bacterial isolates tested showed inhibitory effect on Alternaria macrospora by producing diffusible metabolites by well diffusion assay (Sadfi et al., 2002). Rhizospheric isolate RLS19 and RLS76 $(71.43 \%)$ showed highest inhibition of phytopathogen by producing diffusible metabolites (Fig.7 and Table 2) followed by RLS18 (68.57.00 \%), RLS52， RLS56, RLS96, RLS102 (65.71 \%) and RLS53 $(57.14 \%)$. Our findings compared to others were more effectively controlled the Alternaria macrospora by producing secondary diffusible metabolites.

Rhizospheric bacterial isolates were also screened for siderophore production qualitatively by modified CAS agar plate 
method to avoid the toxicity effect of HDTMA present in CAS blue agar on Gram positive bacterial isolates. Siderophore production was recorded in the form of change in colour from blue to purple or orange (Milagres et al., 1999). CAS agar plate assay indicated that all the rhizobacterial isolates have siderophore production ability; however RLS18, RLS53 and RLS58 found superior compared to other rhizospheric isolates. Similar result was reported by other researchers (Chaiharn et al., 2009). The qualitative production of siderophore shown by $B$. cereus with orange halos during the exponential growth and Sporulation phases on modified CAS plate assay (Lalloo et al., 2010). Our results also similar to earlier author where the rhizospheric bacterial isolates RLS18, RLS52 RLS53 and RLS72 produced orange halos on modified CAS plates (Fig.8) which was indicator of siderophore production.

Overall result indicates that the isolate RLS19, RLS52, RLS18 and RLS102 inhibits the mycelial growth of Alternaria macrospora, causative agent of Alternaria leaf blight of $\mathrm{Bt}$ cotton in vitro. Inhibitory activity was observed due production of volatile metabolites, diffusible metabolites and siderophore production. These isolates have biological control potential by producing secondary metabolites and serve as excellent candidate for the production of commercial biocontrol agent and need to evaluate under field condition.

\section{Acknowledgements}

The authors wish to thank Dr. B. R. Chavan, Principal, Yogeshwari Mahavidyalaya, Ambajogai and Dr. S. B. Parale, Principal, Sant Tukaram Arts and Science College, Parbhani (MS) for providing facilities to conduct the research.

\section{References}

Abbo, A.S., Idris, M.O., and Hammad, A.M. 2014. The Antifungal Effects of Four Tomato Rhizosphere Bacillus spp. against Alternaria Alternata. Int. J. Sci. Res., 3(7): 1324-1328.

Abdalla, S.A., Algam, S.A., Ibrahim, E.A., and El Naim, A.M. 2014. In vitro screening of Bacillus isolates for biological control of early blight disease of tomato in shambat soil. World J. Agri. Res., 2(2): 47-50.

Ajith, P.S., and Lakshmidevi, N. 2010. Effect of volatile and non-volatile compounds from Trichoderma spp. against Colletotrichum capsici incitant of anthracnose on bell peppers. Nat Sci., 8(9): 265-269.

AL-Saeedi, S.S., and AL-Ani, B.M. 2014. Study of antagonistic capability of Trichoderma harzianum isolates against some pathogenic soil borne fungi. Agri. Biol. J. North America, 5(1): 15-23.

Amin, F., Razdan, V.K., Mohiddin, F.A., Bhat, K.A., and Sheikh, P.A. 2010. Effect of volatile metabolites of Trichoderma species against seven fungal plant pathogens in-vitro. $J$. Phytol., 2(10): 34-37.

Arabsalmani, M. 2015. Cotton seed borne disease in Golestan Province in Northern Iran. Cumhuriyet Sci. J., 36(3): 20652070.

Bashan, Y., and Levanony, H. 1987. Transfer of Alternaria macrospora from cotton seed to seedling: light and scanning electron microscopy of colonization. $J$. Phytopathol., 120(1): 60-68.

Bashan, Y., Levanony, H., and Or, R. 1991a. Wild beets as an important inoculum source of Alternaria alternata, a cause of leaf blight of cotton in Israel. Canadian J. Bot., 69(12): 2608-2615.

Bashan, Y., Levanony, H., and Or, R. 1991b. Association between Alternaria macrospora and Alternaria alternata, 
causal agents of cotton leaf blight. Canadian J. Bot., 69(12): 2603-2607.

Bhuiyan, S.A., Boyd, M.C., Martin, C., and Hearnden, M. 2007. Development of Alternaria leaf blight on north Australian cotton (Gossypium hirsutum), species prevalence, and its control using mancozeb. Australasian Plant Pathol., 36(5): 488-497.

Chaiharn, M., Chunhaleuchanon, S., and Lumyong, S. 2009. Screening siderophore producing bacteria as potential biological control agent for fungal rice pathogens in Thailand. World J. Microbiol. Biotechnol., 25(11): 19191928.

Chernin, L., Toklikishvili, N., Ovadis, M., Kim, S., Ben-Ari, J., Khmel, I., and Vainstein, A. 2011. Quorum-sensing quenching by rhizobacterial volatiles. Environ. Microbiol. Reports, 3(6): 698704.

Cook, R.J. 1993. Making greater use of introduced microorganisms for biological control of plant pathogens. Annual Rev. Phytopathol., 31(1): 53-80.

Dalpati, N.N.S., Parate, R.L., and Ingle, S.T. 2010. Efficacy Of some bio-agents and botanicals against Alternaria macrospora causing leaf spot of cotton. J. Plant Dis. Sci., 5(1): 95-97.

Dennis, C., and Webster, J. 1971. Antagonistic properties of species-groups of Trichoderma: II. Production of volatile antibiotics. Transactions of the British Mycological Society. 57(1): 41-IN4.

Dighule, S., Perane, R., Amle, K. and More, P. 2011. Efficacy of chemical fungicides and bio-agents against major cotton fungal foliar diseases in vitro. Int. J. Plant Sci., 6(2): 247-250.

Ellis, M.B. 1976. More dematiaceous Hypomycetes Commonwealth Mycological Institute pub. kew surrev, England.

Gangurde, P.B., Zanjare, S.R., Mehetre, S.S., Rajmane, S.B., and Wayal, C.B. 2003. In vitro evaluation of chemicals and bioagents against Alternaria macrospora Zimm. causing leaf spot of cotton. J. cotton Res. Dev., 17(2): 264-265.

Ghildyal, A., and Pandey, A. 2008. Isolation of cold tolerant antifungal strains of Trichoderma $s p$. from glacial sites of Indian Himalayan region. Res. J. Microbiol., 3(8): 559-564.

Gholve, V.M., Jogdand, S.M., Suryawanshi, A.P. 2014. Evaluation of fungicides, botanicals and bioagents against Alternaria leaf blight caused by Alternaria macrospora in cotton. $J$. Cotton Res. Develop., 28(2): 327-331.

Govindappa, N., Chattannavar, S.N., and Kulkarni, S. 2010. Biochemical studies in $\mathrm{Bt}$ and Non-Bt cotton genotypes against Alternaria blight disease (Alternaria macrospora Zimm.). Karnataka J. Agri. Sci., 21(1): 70-73.

Gull, M., and Hafeez, F.Y. 2012. Characterization of siderophore producing bacterial strain Pseudomonas fluorescens Mst 8.2 as plant growth promoting and biocontrol agent in wheat. African J. Microbiol. Res., 6(33): 6308-6318.

Gveroska, B., and Ziberoski, J. 2012. Trichoderma harzianum as a biocontrol agent against Alternaria alternata on tobacco. Appl. Innov. Technol., 7(2): 6776.

Hebbar, P., Berge, O., Heulin, T., and Singh, S.P. 1991. Bacterial antagonists of sunflower (Helianthus annuus L.) fungal pathogens. Plant and Soil, 133(1): 131140.

Hillocks, R.J. 1991. Alternaria leaf spot of cotton with special reference to Zimbabwe. Int. J. Pest Management, 37(2): 124-128.

Kapadiya, H.J., Butani, A.M., and Khanpara, M.D. 2015. Biological management of major foliar diseases of cotton. J. Cotton Res. Develop., 29(1): 108-111.

Lalloo, R., Moonsamy, G., Ramchuran, S., Görgens, J., and Gardiner, N. 2010. Competitive exclusion as a mode of 
action of a novel Bacillus cereus aquaculture biological agent. Lett. Appl. Microbiol., 50(6): 563-570.

Lamsal, K., Kim, S.W., Kim, Y.S., and Lee, Y.S. 2012. Application of rhizobacteria for plant growth promotion effect and biocontrol of Anthracnose caused by Colletotrichum acutatum on Pepper. Mycobiol., 40(4): 244-251.

Milagres, A.M., Machuca, A., and Napoleao, D. 1999. Detection of siderophore production from several fungi and bacteria by a modification of chrome azurol $S$ (CAS) agar plate assay. $J$. Microbiol. Methods, 37(1): 1-6.

Otadoh, J.A., Okoth, S.A., Ochanda, J., and Kahindi, J.P. 2011. Assessment of Trichoderma isolates for virulence efficacy on Fusarium oxysporum f.sp. Phaseoli.Tropical and Subtropical Agroecosystems, 13: 99-107.

Pryor, B.M., and Michailides, T.J. 2002. Morphological, pathogenic, and molecular characterization of Alternaria isolates associated with Alternaria late blight of pistachio. Phytopathol., 92(4): 406-416.

Rajput, R.B., Solanky, K.U., Prajapati, V.P., Pawar, D.M., and Suradkar, S.R. 2013. Effect of fungal and bacterial bioagents against Alternaria alternata (fr.) Keissler in vitro condition. The Bioscan, 8(2): 627-629.
Rane, M.S., and Patel, M.K. 1956. Diseases of cotton in Bombay I. Alternaria leaf spot. Indian Phytopath., 9(2): 106-113.

Sadfi, N., Cherif, M., Hajlaoui, M.R., Boudabbous, A., and Belanger, R. 2002. Isolation and partial purification of antifungal metabolites produced by Bacillus cereus. Annals of microbiol., 52(3): 323-338.

Saha, D., Purkayastha, G.D., Ghosh, A., Isha, M., and Saha, A. 2012. Isolation and characterization of two new Bacillus strains from the rhizosphere of eggplant as potential biocontrol agents. J. Plant Pathol., 94(1): 109-118.

Sandheep, A.R., Asok, A.K., and Jisha, M.S. 2012. Biocontrol of Fusarium wilt of vanilla (Vanilla planifolia) using combined inoculation of Trichoderma $s p$ and Pseudomonas sp. Int. J. Pharma and Bio Sci., 3(3): 706-716.

Thakur, S., and Harsh, N.S.K. 2014. Phylloplane fungi as biocontrol agent against Alternaria leaf spot disease of (Akarkara) Spilanthes oleracea. Biosci. Disc., 5(2): 139-144.

Whipps, J.M. 1987. Effect of media on growth and interactions between a range of soil-borne glasshouse pathogens and antagonistic fungi. New

\section{How to cite this article:}

Laxman S. Raut and Venkat S. Hamde. 2016. Screening of Antifungal Potential of Rhizospheric Isolates against Alternaria Leaf Blight Disease of Bt-cotton in vitro. Int.J.Curr.Microbiol.App.Sci. 5(8): 769-784. doi: http://dx.doi.org/10.20546/ijcmas.2016.508.086 